УДК 02(34)(091)

091(34)

003.336

doi: 10.19090/cit.2019.34.40-51

Прегледни рад

\title{
Књига и библиотеке у Старој Индији
}

\author{
Анђела Стошић \\ Универзитет у Београду \\ Филолошки факултет - Катедра за библиотекарство и информатику, Београд \\ andjela.stosic@fil.bg.ac.rs
}

\begin{abstract}
Сажетак
У овом раду учињен је покушај да се домаћој библиотечкој јавности представе улога и значај књиге и библиотека на индијском потконтиненту. Приказан је однос према књизи и писању, као и ток оснивања библиотека у најстаријем развојном периоду, између 3000. г. п.н.е. и 1206. г. н.е. Систем писања који још увек чека да се дешифрује, постојао је у цивилизацији долине реке Инд још у 3. миленијуму пре нове ере, о чему сведоче бројни печати од стеатита и бакарне плочице са записима. О постојању рукописних збирки пре нове ере на просторима Индије се најмање зна, чему је узрок, осим велике временске дистанце, врло развијена усмена традиција преношења знања. Још један од разлога је пракса писања на материјалима који нису превише трајни, а то су најчешће палмин лист и брезина кора. Најпоознатији текстови у данашње време су Закони краља Ашоке записани на камену, који потичу из трећег века пре наше ере. Прве библиотеке у старој Индији о којима се поуздано може говорити, налазиле су се у склопу махавихара, будистичких монашких универзитета. Најпознатија и највећа међу њима је библиотека у Наланди. Поред библиотека при центрима образовања, у старој Индији издвајају се дворске библиотеке и библиотеке при религијским центрима.
\end{abstract}

Кључне речи: стара Индија, књига, писмо, писање, материјали за писање, махавихара, дворске библиотеке, библиотеке при образовним центрима, библиотеке при религијским центрима

\section{Увод}

Историја Индије у научној литератури посматра се кроз четири развојна периода: стари (3000. г. п.н.е. - 1206. г. н.е.), средњовековни (1206-1757), британски (1757-1947) и период независне Индије, који траје до данас. Циљ овог рада је да ближе представи однос према књизи и писању, као и ток оснивања библиотека током првог, најстаријег периода. Синтагма стара Индија користи се да означи територију данашње Републике Индије, али се односи и на просторе који јој данас не припадају, а то су делови данашњег Пакистана, Бангладеша, Непала, Бутана и Шри Ланке.

Систем писања, који још увек чека да се дешифрује, постојао је још у 3. миленијуму пре нове ере, о чему сведоче бројни печати од стеатита ${ }^{1}$ и бакарне плочице са записима пронађеним на просторима северозападне Индије и већег дела Пакистана. О цивилизацији у долини реке Инд још увек се не зна много и већи део локалитета још увек није истражен, али се ипак претпоставља да су библиотеке могле бити део ње. Аријевци² на ове просторе долазе средином другог миленијума, када почиње период који се назива Ведским ${ }^{3}$ и траје до 6. века пре нове ере.

О постојању рукописних збирки на овим просторима пре нове ере нема података, чему је узрок, осим велике временске дистанце, врло развијена усмена традиција преношења знања. Још један од разлога је пракса писања на материјалима који нису превише трајни, али и велика

\footnotetext{
1 Стеатит или талк (назива се још и сапунасти камен јер при додиру подсећа на сапун) је минерал који се лако може обрађивати. Разноврстан је по боји и тврдоћи. Нордијски је погодан за подове, зидне плоче и пећи, док је за вајарство потребан мекши камен са простора Кине, Тајланда, Аустралије и Африке.

2 Народ из централне Азије који на тло индијског потконтинента долази преко планина Хиндукуш.

3 Веде су древни индијски текстови по којима је овај период добио име. Веда на санскриту значи знање.
} 
разарања храмова и библиотека током муслиманских освајања, која ће, успостављањем султаната широм Индије 1206. године, отворити другу етапу индијске историје библиотека.

Да су људи у Старој Индији били посвећени прикупљању и преношењу знања, говоре де-

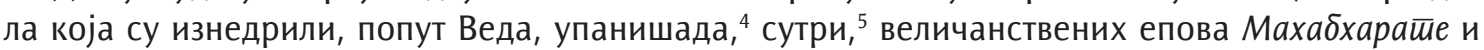
Рамајане, као и филозофска дела великих мудраца и значајни обим будистичких списа. „Примарно религијског типа, а привилегија свештеничке касте, обиман део литературе у старој Индији одржаван је усменим предањем и није био доступан у писаној форми." 6

Први поуздани извори који указују на постојање својеврсних библиотека на просторима Индије потичу из седмог века наше ере. Библиотеке које су се у овом и у каснијим вековима развијале најчешће су се налазиле у оквиру образовних центара. Поред њих, у Старој Индији постојале су и дворске, као и библиотеке при религијским центрима.

\section{Тајанствено писмо древне цивилизације у долини реке Инд}

Како је писмо основни предуслов за постојање књига, а затим и библиотека, овај одељак посвећен је првом поглављу у историји старе Индије и једном, у научној јавности досад неразјашњеном систему писања, коришћеном пре око 4000 година.

Цивилизација у долини реке Инд развијала се између 2600. и 1900. године пре нове ере. Најзначајнија средишта били су Харапа ${ }^{7}$ и Мохенџо Даро, ${ }^{8}$ док је највећи број насеља био сеоски. Више од хиљаду села и градова пронађено је на простору од 800.000 квадратних километара који данас припада Пакистану и северозападној Индији. ${ }^{9}$

За разлику од Месопотамије и Египта, који су дуго предмет изучавања и дивљења западног света, ова комплексна култура смештена у јужној Азији, са популацијом која је на врхунцу развоја могла достићи 10 процената становника света, почиње да се проучава тек 1920. године. Од тада је велики број археолошких истраживања открио развијену урбану културу са бројним трговачким путевима и поморским везама са Месопотамијом, ${ }^{10}$ стандардима за изградњу објеката, санитарним системима, развијеном уметношћу и занатима и још увек недешифрованим писмом. Јавне грађевине су биле од опека једнаке величине, куће изграђене око средишњег дворишта. Овдашњи људи улепшавали су се накитом од злата и драгог камења. Упечатљиво је и то да нису пронађени трагови ратовања и војне опреме.

Иако археолошка истраживања још увек нису резултирала проналаском неке значајније организоване збирке те се не може још увек са сигурношћу тврдити, постоје извори који наводе да су се у урбаним центрима могле налазити и грађевине намењене чувању исписаних цилиндричних печата и таблица. ${ }^{11}$

Поред печата од стеатита, записи су овековечени на глиненим и бакарним таблицама. Најчешће је у питању ред пиктографских знакова испод којих су људски или животињски мотиви. Више од стотину покушаја дешифровања индуских знакова објављено је након 1920. године. Истраживачи су износили различите ставове и теорије о овом писму, али до сада није постигнут консензус око значења записа.

\footnotetext{
${ }^{4}$ Упанишаде су хиндуистички текстови, најчешће у форми дијалога, који образлажу садржину Веда.

${ }^{5}$ Сутре су поучни говори Буде или ученика који су живели у његово време.

${ }^{6}$ Jashu Patel and Krishan Kumar, Libraries and Librarianship in India (Westport: Greenwood Press, 2001), 2. (Прев. А. С.)

7 Локалитет некадашњег града налази се поред села Харапа у источном Пакистану, по коме је и добио име.

${ }^{8}$ Остаци града Мохенџо Даро налазе се $20 \mathrm{~km}$ од Ларкане и $80 \mathrm{~km}$ од Сукура у данашњем Пакистану. Уврштен је у UNESCO листу светске баштине. Назив града је синдском језику и значи „град мртвих".

${ }^{9}$ Andrew Robinson, "Ancient civilization: Cracking the Indus script", Nature Vol. 526 (22. 10. 2015): 499, preuzeto 15. 8. 2018, https://www.nature.com/news/ancient-civilization-cracking-the-indus-script-1.18587.

10 На остацима месопотамског града Ура нађени су предмети исписани индуским знаковима, што указује на сарадњу међу заједницама.

${ }^{11}$ Encyclopedia of Library and Information science, Vol. 39, supplement 4, "India, academic libraries in", 203.
} 
Први проблем је још увек неоткривено порекло овог језика. Наука није утврдила да ли је у питању предак санскрта, ${ }^{12}$ дравидског, или припада некој другој индијској породици језика, као нпр. мунда, или је настао од неке изумрле породице језика. Друга отежавајућа околност је то што није сачувано ниједно име индуског владара или друге личности из митова или историјских извора, попут Рамзеса или династије Птоломеја, за које су истраживачи хијероглифа знали на основу записа о старом Египту на грчком. Такође, досада се није дошло ни до каквог вишејезичног споменика налик Розеш̄и¹3 који би помогао у дешифровању индуског писма. Дужина записа је још једна од препрека. Ниједан пронађени текст не чини више од 26 карактера.

Упркос набројаним препрекама, научници су последњих деценија много постигли. ${ }^{14}$ Из- $^{3}$ ванредан корпус фотографија индуских записа, ${ }^{15}$ који је уредио Аско Парпола, индолог на Универзитету у Хелсинкију, објављиван је између 1987. и 2010. године. Ово дело незаобилазан је извор за проучавање индуског писма. За сада је познат смер писања - здесна налево. Идентификовано је више стотина различитих знакова. Делимично је разјашњена сегментација текстова који садрже поновљене секвенце карактера, синтаксичке структуре, као и нумерички и метрички систем. ${ }^{16}$

Мистериозна цивилизација нестала је око 1700. године пре нове ере, као и њено тајанствено писмо које није оставило никаквог трага у писмима која ће се касније развити у Индији. ${ }^{17}$ Период који следи назива се ведским, по најстаријим и најзначајнијим светим списима у Индији, и траје до 6. века пре наше ере. Веде, које настају негде између 1800. и 1500. године п.н.е, јако дуго ће постојати не у форми текста, већ као знање које се преноси искључиво усменим путем, а записиване су тек од 11. века. ${ }^{18}$ Данас се сматрају темељем индијске културе и религије и чине основу онога што се зна о овом временском периоду.

\section{Истрајно усмено предање и однос према писању}

Сматра се да се санскртско писмо (нагари, или деванагари) јавља око 10. века п.н.е. Упркос томе, филозофија и књижевност се у раним периодима у Индији, као и у већини старих култура, заснивају и преносе претежно усменим путем. Кинески ходочасник, И-Тсинг, који у Индији борави у другој половини 7. века наше ере, бележи да се „Веде уче од уста до уста и не записују на папир. У свакој генерацији има учених брамана који знају наизуст тих 100.000 стихова“. ${ }^{19}$

Pī-веga, ${ }^{20}$ која садржи збирку од десет књига химни упућених разним божанствима, састоји се од 1017 песама, 10.580 стихова или око 153.826 речи. Поставља се питање „како су ове песме састављене - јер су написане у савршеном метру - и како су, након што су сачињене, чуване од 1500. године пре Христа до 1500. након Христа, у времену коме већина најбољих санскртских рукописа припадају?

\footnotetext{
12 Санскрт је класични језик из групе индоаријских језика стар око 3500 година.

13 Камен из Розете садржи текст закона из периода владавине династије Птоломеја у Египту. Закон је на камену написан на три писма те је његов проналазак 1799. године био кључан за дешифровање хијероглифа.

14 Напредак технологије подстиче наду да је дешифровање све ближе. Највећи део налазишта још увек чека да буде истражен, за сада је обрађено тек око $10 \%$ локалитета. Немирно погранично подручје отежава напредак истраживања те многи обећавајући локалитети чекају да открију своју историју. Такав је нпр. град Ганверивала, откривен седамдесетих година 20. века, по величини у рангу са Мохенџо Даром и Харапом.

15 Фотографије су један од резултата Харапа археолошког истраживачког пројекта (HARP), започетог 1986. године

${ }^{16}$ Robinson, "Ancient civilization: Cracking the Indus script...": 500.

17 Не зна се поуздан разлог ишчезавања ове цивилизације. У литератури се спомињу два - значајна климатска промена и налети Аријеваца. Могуће је и то да су и један и други узрок имали свој удео.

18 Dušan Pajin, "Staroindijsko narativno nasleđe - budistička i hinduistička tradicija“, Исӣок: раgови са науиної скуйа оgржаної у Новом Cagy 6 јуна 2014. іоgине, ур. Никола Грдинић (Нови Сад: Завод за културу Војводине, 2015), 128.

19 I-Tsing, A record of Buddhist Religion as Practised in India and Malay Archipelago A.D., 671-695 (Delhi: Munshiram Manohorlal Publishers, 1966), 182, citirano u Dušan Pajin, Nav. delo, 127.

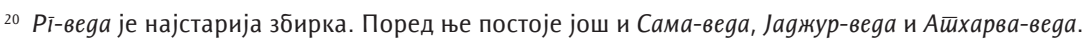


Самойамћењем... да је сваки рукопис Рї-веge изгубљен, могли бисмо да повратимо њену целокупност из памћења Сротрија у Индији. Ови домородачки ученици уче Веду напамет и уче је из уста њиховог Гуруа, никада из рукописа..." 21

Учење Веда напамет пракса је која не важи само за стари век. Макс Милер, на крају 19. века, говори о истоветној појави као и И-Тсинг у седмом - у време његовог боравка у Индији постојао је велики број учењака „који би, ако би желели, могли да запишу свако слово, сваки акценат, управо онако каквим их налазимо у нашим старим рукописима“. Милер ове људе назива „живим библиотекама“ те сматра да његови пријатељи који одлазе у Индију имају дужност да покушају да науче све што се још увек може научити од њих. ${ }^{22}$

Прича о Ведама подсећа да су људи, уздајући се у најсавршенији медиј за складиштење човеков ум, успели да одрже текст, који је, према речима Душана Пајина, захваљујући томе остао јединствен на најразличитијим крајевима индијског потконтинента.

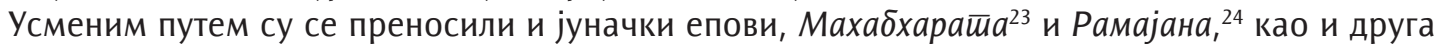
славна дела староиндијске књижевности и филозофије, историјска дела, биографије и, наравно, свете књиге бројних индијских религија. Ипак, постоје извори који указују да, у епском добу (од око 1000. г. п.н.е. до 600. г. п.н.е.), читање и проучавање рукописа није била непозна-

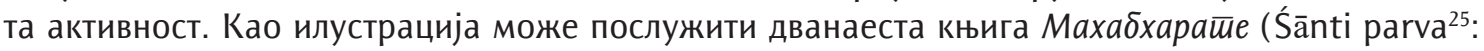
„Књига мира“) где се налази обраћање Махараџи Јанаку (краљ Видехе) које гласи:

„Ваше Височанство, Ви сте проучавали Веде и друге шастре ${ }^{26}$ али нисте разумели суштину њихову. Ваше учење Веда и других шастри није уродило плодом. Они који могу да изучавају Књиге а не могу да разумеју њихово унутрашње значење, уче узалуд. Такви само носе терет књига. Учење постаје плодоносно само за оне који истински разумеју значење и могу ваљано да одговоре на питања из књига."

Овај одломак јасно говори о постојећој пракси читања рукописа, али и указује на њене недостатке и потребу за усменим преношењем знања и исправним тумачењем записа. ${ }^{27}$

Прекретницу у односу према писању донеће будизам, који се у Индији рађа у другој половина 6. века пре нове ере, ${ }^{28}$ а са њим се јавља и идеја о ширењу знања. Већ током Будиног ${ }^{29}$ живота оснивају се прве санге, монашке заједнице. Многи Будини ученици били су брамани и

21 Фридрих Макс Милер, Bege: иему нас Инgија може науиитии (Београд: Пешић и синови, 2005), 158.

22 Исто, 159

23 Махабхараша представља највећи индијски, али и светски еп. Име му је скраћеница од пуног назива који се у самом тексту налази у две варијанте: „Велики еп о племену Бхарата“ и „Еп о великој бици Бхарата“. Постоје и две верзије текста - северна, са преко 80.000, и јужна, са скоро 95.000 шлока (32 слога). Сматра се да је полазно језгро имало око 8000 шлока, а да је касније увећавано. Састоји од 18 књига, где су неки делови у стиху, али има и прозних деоница. Историчари оквирно одређују да је Махабхараша а највећим делом уобличена у распону од око 800 година - од 400. г. п.н.е. до 400. г. н.е. - али да епска окосница потиче из даље старине. Видети: Pajin, Nav. delo, 135-136.

24 Рамајана је други велики еп индијске традиције који се састоји од око 24.000 шлока, а настајала је по неким схватањима у исто време кад и Махабхараш̄а, а по другима нешто касније (између 3. века старе и 3. века нове ере). Има три рецензије: северну, западну и бенгалску. По предању, аутор је Валмики (4-3. век старе ере) и његова полазна верзија знатно је краћа. Временом Рамајана стиче статус верског списа додавањем првог и седмог поглавља, у којима се Рама приказује као отелотворење бога Вишнуа. На почетку је еп био више повезан са дворском средином, а касније стиче популарност у целом друштву.

25 Санкскртски термин „парван“ којим су означени делови овог епа преводи се речју „одељак“, међутим, због обима ових одељака прикладније је рећи да се Махабхараш̄а састоји од 18 књига или томова. Њима се у неким варијантама придружује и 19. књига - Харивамша која је само оквирно повезана са осталим текстом, али се казивала у истој прилици кад и Махабхараша.

26 Шастра (Śāstra) - санскртска реч која означава правило, упутство, књигу или трактат. У ширем смислу може бити знање о некој теми или ужој области науке. (Прим. А. С.)

27 Bimal Kumar Datta, Libraries and Librarianship of Ancient and Medieval India (Delhi: ATMA RAM \& SONS, 1960$), 15$

28 Иако је, према званично признатој историјској периодизацији, реч о старом веку, Александар Петровић сматра да се, управо у будизму, човек поставља у средиште космичког збивања и да је због тога овде тачка од које почиње модерна историја Индије. Видети: Александар Петровић, Og Наланgе gо Хиланgара (Нови Сад: Матица српска; Београд: Филолошки факултет Универзитета, 2017), 23.

${ }^{29}$ Сидарта Гаутама (560. г. п.н.е. -486 . г. п.н.е.). 
већ су владали памћењем текстова, па је најпре та вештина коришћена да се сачувају Будине проповеди, разговори и изреке. ${ }^{30}$

Писменост је у првим вековим будизма била цењено умеће, пре свега за администратора или хроничара, док је за размену и одржавање духовних вредности мање битна или чак другоразредна. ${ }^{31}$ Трговци су се такође служили писмом, о чему се закључује на основу записа Hеарха, официра Александра Великог. Мегастен, ${ }^{32}$ пак, сведочи да закони Индијаца нису били писани, већ да су спроводили правду по сећању. ${ }^{33}$

Будизам се значајно развија и добија нове следбенике за време династије Маурија, тачније током владавине краља Ашоке (273-236). ${ }^{34}$ Краљ је најпре сам прешао у будизам, а затим је утицао да га прихвате и његови поданици. Управо из овог периода потичу најстарији сачувани споменици писани индијским писмима ${ }^{35}$ - Закони краља Ашоке уклесани у камену.

Усмена традиција је и даље доминирала те се велики будистички спис Трийийака записује тек при самом крају старе ере у Шри Ланки, а Сиgханша свети спис џаинизма, још касније - у 5. веку нове ере, иако је џаинизам у то време већ стар око хиљаду година. ${ }^{36}$

\section{Материјали за писање}

Природа је индијским народима нудила најразличитије подлоге за писање, од којих су се многе употребљавале и у новијим вековима, иако је папир ушао у употребу у 12. веку, а Кина, као његова постојбина, била веома близу. Бројни су материјали који су се у старој Индији користили за записивање и они су се у великој мери разликовали од оних на простору Европе и западне Азије. Избор материјала на коме ће нешто бити записано зависио је од његове доступности у природи, али и од садржаја записа. Натписи на камену били су уобичајени за текстове комеморативне садржине и посвете, док су се религијски и секуларни садржаји налазили претежно на бронзи. За књижевност су, пак, били подобнији палмино лишће, брезина кора и памучна одећа. Трагови коришћења папируса нису сачувани до данас, мада се зна да је употребљаван у 4. веку пре нове ере. „Најстарији текст написан на палмином листу потиче из 4. века наше ере, међутим, он није нађен у Индији јер су климатски услови били неповољни за чување тако крхког материјала, него у средишњој Азији. Ретки фрагменти на брезиној кори су нешто старији, а чешћи налази тог материјала потичу тек из 12. века и даље." ${ }^{\prime 37}$

Палмин лист истиче се као најчешћи материјал за писање у старој Индији. Палмино дрво расло је претежно у јужној Индији и у приморским деловима. Лишће се за писање припремало сушењем на сунцу, да би се затим прокувало у води, а онда опет сушило. Томе је следио поступак глачања каменом или шкољком. Лист се секао на мање делове по потреби и био је спреман за писање. ${ }^{38}$ Писало се на два начина. У јужној Индији и Ориси ${ }^{39}$ слова су се уцртавала оштрим пером или стилусом. У северној Индији писало се мастилом. Ради повезивања,

\footnotetext{
30 Pajin, Nav. delo, 128

31 Isto, 127.

32 Мегастен (око 350-290. г. п.н.е.), старогрчки историчар, описао је Индију у свом делу Инgика, које није сачувано, али се о његовој садржини понешто зна из текстова аутора који су после њега писали.

33 Милер, Нав. дело, 157

34 Не постоје прецизни подаци о томе када је краљ Ашока био на престолу. Године у тексту наведене су према Aleksandar Stipčević, Povijest knjige (Zagreb: Nakladni zavod Matice Hrvatske, 1985), 50. Макс Милер наводи да је краљ Ашока владао од 259. до 222.

35 У натписима из времена краља Ашоке у употреби су два писма - кхароштхи и брахми.

${ }^{36}$ Stipčević, Povijest knjige, 50.

37 Isto.

38 Kumar Datta, Nav. delo, 105.

39 Држава у источној Индији.
} 
листови су се ређали један на други и бушили на средини или са стране, како би се провукао канап. Рукописи од палминог лишћа нису трајали дуго на простору јужне Индије, насупрот томе, клима на северу Индије и Непалу им је одговарала.

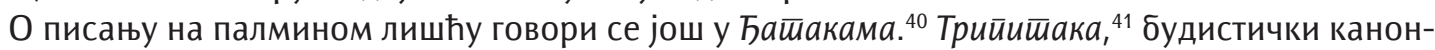
ски текст, први пут је записана управо на овом материјалу. Палмино лишће користило се и током средњег века, а у 18. и 19. веку, у сеоским школама, деца су на њему учила да пишу. ${ }^{42}$ Сачувани рукописи потичу из другог, четвртог и каснијих векова. ${ }^{43}$

Брезова кора је други значајни материјал за писање у старој, али и у средњовековној Индији. Најранија потврда о њеном коришћењу налази се у делу Исйорија Алексанgра Великої (Historiae Alexandri Magni) Квинта Курција Руфа, који наводи да су у време Александрових освајања Хиндуси писали на брезовој кори.. ${ }^{44}$ За писање се припремала тако што се најпре одвајала од дрвета и делила на плоче различитих величина. Кора се затим премазивала уљем и глачала. Тако припремљени листови ређани су један на други и бушени су ради повезивања. Рукопис се на крају коричи дрвеним дашчицама. Просечне димензије листова приближно износе 90х20 центиметара.

Овај материјал користио се и у средњем веку, али и дан-данас за понеке свете текстове или религиозне песме. ${ }^{45}$

Делови памучне одеће такође су коришћени за писање у старој Индији, мада не колико палмино лишће и брезова кора. Како би се начинила погодном за писање, најпре се на њу наносио дебљи слој пиринчане или пшеничне каше. Када се осуши, површина је глачана шкољком или каменом како би постала сјајна и спремна за писање. Најстарија сачувана документа су из 15. века, али се овај материјал спомиње у текстовима Неарха.

Осим палминог, листови банане, лотоса и других локалних биљака били су такође интересантни. Нешто чвршћа подлога, поред брезове, била је и кора дуда (Morus Indica). Глинене таблице и на овим просторима биле су неизоставне, док су се дрвене таблице правиле од шкриљца и бамбуса. Писало се: мастилом, писаљкама од метала, бамбуса, дрвеним гранчицама, сламчицама, трскама. ${ }^{46}$ Писање на дрвеним таблама практиковано је у Индији од најранијег доба па све до данас. Постоји текст о правном поступку који препоручује да би жалбе требало писати кредом на таблама. ${ }^{47}$

\section{Библиотеке}

У периоду старе Индије забележено је постојање три типа библиотека: при палатама/дворовима, при центрима богослужења и оне при центрима учења. Данашње знање о овим библиотекама је оскудно, а већина података позната је на основу записа ходочасника, претежно из Кине, који су, у периоду између 4. и 11. века, облазили будистичка света места и манастире проучавајући и преписујући рукописе.

Подаци о дворским библиотекама врло су фрагментарни. Као и у другим деловима света, краљевске библиотеке често су биле део плена, отимане су или уништаване. Историји су

\footnotetext{
40 Ђашиака је збирка 547 прича о догађајима из Будиних пређашњих живота. Сматра се да потиче из 4. или 3. века старе ере у облику усменог предања, док је писана верзија настала неки век касније. Аутори су анонимни, а сматра се да су током векова додаване приче полазној збирци и да је коначна формирана почетком наше ере.

41 Назив потиче из санскрта и значи три корпе. Корпе представљају учења од којих се Трийишака састоји (сутре, винаја и абидарма), а сама реч pitaka означава корпу или кутију од дрвета или бамбуса у којој су се држали рукописи од палминог лишћа.

42 Kumar Datta, Nav. delo 106.

43 Ibid., 107.

44 Ibid., 109

45 Ibid., 108-109

46 Ibid., 104.

47 Ibid., 112
} 
позната имена тек неколико краљева који су имали библиотеке на својим дворовима.Краљ Харша Вардхана (7. век) ${ }^{48}$ имао је велику библиотеку у Канауџу. ${ }^{49}$ Ово се може сазнати из извештаја према коме је краљ дао неколико товара књига Шен Зонгу. ${ }^{50}$ Детаљи о уређености или обухвату ове библиотеке нису познати, али се закључује да је била велика и у квалитативном и у квантитативном смислу. ${ }^{51}$ Из записа Шен Зонга зна се и за постојање дворске библиотеке у Гандхари за време краља Канишке 52 (1. век н.е.). За време свог боравка на овим просторима у 7. веку, Шен Зонг сведочи о лепом гостопримству на двору, где је имао приступ колекцији списа, као и обезбеђене преписиваче.

Зна се и да је династија Чалукија ${ }^{53}$ поседовала на двору велику збирку књига која је носила назив „Bharati Bhandagara”, што би значило Бхаратино ${ }^{54}$ складиште. ${ }^{55}$

Хинду владари попут Бхоџе (1010-1055) и центри браманистичке културе, као што је Митила, предузимали су иницијативе у оснивању библиотека. ${ }^{56}$

Будисти у Индији, попут бенедиктинаца у Европи, давали су посебан значај преписивању рукописа и њиховом прикупљању. Поред њих, ђаини и хиндуси су такође дали значајни допринос на пољу учења. Били су покровитељи образовања, основали су бројне храмове и школе у оквиру њих. ${ }^{57}$ Тако су будистички и ђаинистички манастири били својеврсни репозиторијуми знања, било да су у питању религијски текстови, или неке друге области.

Будистички манастири или махавихаре временом су се развиле у институције високог образовања и стекле високу репутацију и ван граница Индије. ${ }^{58}$ Поред учења, подстицале су преписивање, исправљање и превођење рукописа, промовисале су индијску културу међу другим земљама. Свака је имала пригодну библиотеку која је служила хиљадама студената из Индије и других земаља.

У библиотеке при центрима образовања махом су сврстане збирке рукописа које су се чувале у оквиру махавихара, будистичких манастирских комплекса, које се у великом броју оснивају од 8. века у источној Индији. Махавихаре под својим окриљем развијају монашке универзитете. У манастирима је обично било смештено на хиљаде монаха, које су обучавали еминентни учитељи будистичке филозофије и праксе. Наставни план средњовековних индијских универзитета укључивао је теорију религије и граматику, лингвистику, дебату, реторику, астрологију, математику, систем ајурведске медицине, музику и сликарство. Све ово захтевало је литературу која се чувала и умножавала у пригодним библиотекама. ${ }^{59}$

\footnotetext{
48 Рођен око 590. године, владао од 606. до 647. године, када умире. Упамћен је као први владар који је успоставио дипломатске односе између Индије и Кине. Краљ Харша је, као велики мецена, финансирао хроничара Банабхату и лирског песника Мајуру. И сам је био песник, аутор три представе на санскрту: Наїананgа, Райнавали и Пријаgаршика. Видети: Encyclopaedia Britannica, s.v. "Harsha: Indian Emperor", preuzeto 17.9.2018, https://www.britannica.com/biography/Harsha.

49 Град у Утар Прадешу, налази се $80 \mathrm{~km}$ од реке Ганг. Канауџ је у 7. веку био престоница краљевства које је обухватало велики део северне Индије. Значајно се развијао током 9. и 10. века, када су саграђени бројни хиндуистички храмови и будистички манастири. Велико разарање град је доживео 1018. године, када га је освојио султан Махмуд и постао је део Газнавидског царства.

50 Шен Зонг (Hiuen-Tsang) је будистички ходочасник из Кине који је у Индији боравио од 629. до 645. године и оставио за собом изузетно значајне записе на основу којих се може реконструисати историја књиге и библиотека овог доба.

51 Mohamed Tahner and Donald Gordon Davis Jr, Librarianship and Library Science in India: An Outline of Historical Perspectives (New Delhi: Concept Publishing Company, 1994), 29.

52 Овај владар из династије Кушан, познат као велики поштовалац и покровитељ будизма, владао је северним делом индијско потконтинента, Авганистаном и деловима централне Азије.

53 Краљевска династија која је владала различитим деловима јужне и централне Индије од 6. до краја 12. века.

54 Бхарати је име хиндуистичке богиње знања и музике.

55 Превод аутора.

56 Kumar Datta, Nav. delo, 26.

57 Ibid., 26

58 Sumeer Gul and Samina Khan, "Growth and Development of Oriental Libraries in India", Library Philosophy and Practice (April 2008): 1, preuzeto 15. 8. 2018,234477140_Growth_and_Development_of_Oriental_Libraries_in_India.

59 S. Kumar, "Buddhist Monasticism And Education System: A Case Study Of India Korea, Thailand And Tibet" (doktorska dis., Faculty of Humanities and Languages, Jamia Millia Islamia, New Delhi, 2016), 62, preuzeto 30. 1. 2019, http://hdl.handle. net/10603/211620.
} 
Најстарије седиште високог образовања у Индији јесте Таксила у Гандхари и, према неким теоријама, може се сматрати првим универзитетом на свету. ${ }^{60}$ Радио је око хиљаду година (до 5. века н.е.). Постоји податак да је у једном периоду уписивао по 500 студената. Изучавали су се Веде, филозофија и будизам. Може се окарактерисати као својеврсна престоница тадашњег високог образовања. Иако археолошких података о постојању библиотеке нема, у изворима се наводи да је класификацију списа успоставио Панини, познати индијски научник, филолог, аутор величанствене санскртске граматике у безмало 4000 стихова. Данас, нажалост, није познато какав је то систем класификације био. ${ }^{61}$ Колекција је обухватала хиндуистичке списе, дела из политичких наука, књижевности, медицине, филозофије, стрељаштва. Овај универзитет је, заједно са градом, унштен током инвазије Хуна средином 5. века. ${ }^{62}$

Седиште образовања о коме се зна нешто више јесте Наланда махавихара. Налази се на око 60 километара северозападно од Патне и до почетка 5. века била је само једно сеоско насеље које ће се развити захваљујући владарима из династије Гупта (280-554). ${ }^{63}$

Краљ Кумарагупта (415-455) саградио је будистички манастир у Наланди који је већ 450. године постао образовни центар познат и ван граница Индије. ${ }^{64}$ Кумарини наследници такође ће бити покровитељи ове институције захваљујући којима ће она прерасти у својеврсни универзитет који ће радити све до 1205. године.

Многи путници и ходочасници посетили су Наланду. Овде би набављали будистичке списе и учили право значење њихових доктрина. Зна се да је, за време боравка Шен Зонга у Индији, у Наланди студирало 5000 људи. Ји Цинг (у Индији од 673. до 695) такође је похађао ово реномирано училиште у коме је тада боравило више од 3000 студената. Поред учења, професори и студенти у Наланди били су ангажовани на преписивању рукописа, од којих су неки сачувани до данашњих дана и могу се наћи у Бодлеани, као и у библиотеци Краљевског азијског друштва Велике Британије и Ирске и Библиотеци Азијског друштва у Западном Бенгалу. ${ }^{65}$
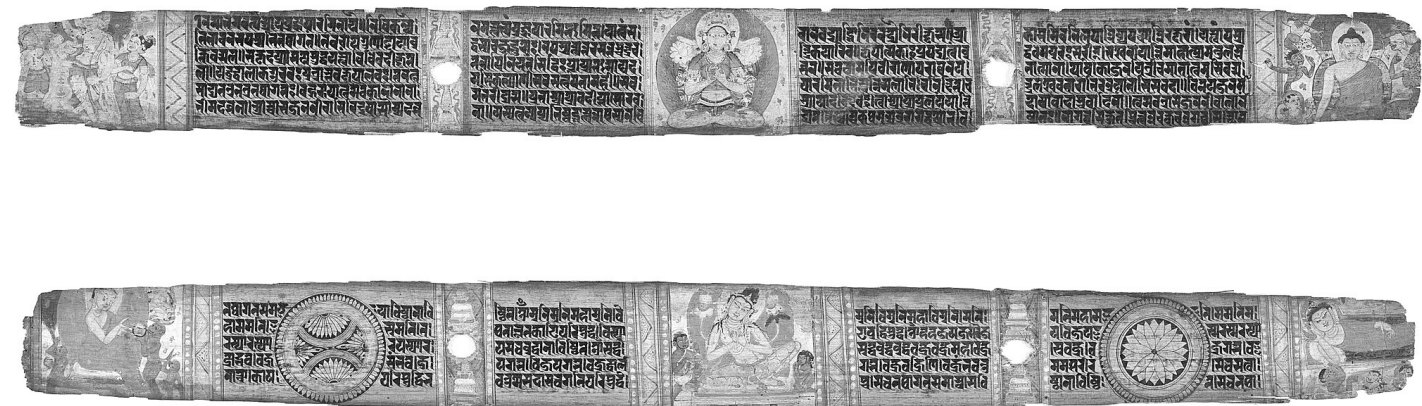

\section{Слика бр. 1 - Странице рукописа на палмином листу (Наланда, око 1075)}

Нзвор: LACMA, preuzeto 18. 3. 2019, https://collections.lacma.org/node/238275.

\footnotetext{
${ }^{60}$ Girdhari Lai Trehan, Learning and Libraries in Ancient India: A Study (Chandigarh: Library Literary House, 1975$), 33$.

${ }^{61}$ Tahner and Gordon Davis Jr, Nav. delo, 31.

${ }^{62}$ Encyclopedya of Library and Information science, s.v. "India, academic libraries in", 203.

63 Династију Гупта основао је махараџа Гупта 280. године, али се она учврстила тек четрдесетак година касније, за време владавине његовог унука Чандрагупте I, откада почиње такозвана „класична епоха“ у историји Индије. У овом периоду развијаће се наука, филозофија, уметност, књижевност. Иако је највећи утицај имао будизам, владаре овог доба одликује верска толеранција која ће омогућити спајање различитих традиција.

${ }^{64}$ Raksesh Kumar Bhatt, "Academic Libraries in India: A Historical Study" (rad predstavljen na konferenciji International Conference on Academic Libraries: Vision and roles of the future academic libraries, New Delhi, India, 5-8. oktobar 2009), 56, preuzeto 20.8.2018, http://crl.du.ac.in/ical09/papers/index_files/ical-10_180_494_2_RV.pdf.

${ }_{65}$ Kumar, "Buddhist Monasticism And Education System: A Case Study Of India Korea, Thailand And Tibet", 88
} 
Велелепна библиотека у Наланди носила је назив Дхармаганђа (Dharmaganja) који у преводу значи „тржиште религије“ (Piety Mart). Да су овде књига и библиотека сматрани драгоценошћу доказују имена трију зграда од којих се састојала Дхармаганђа: Ратнасагара - Океан драгуља, Ратнудади - Море драгуља, и Ратнаранђака - Опточена драгуљима. Највећа међу њима, Ратнасагара, била је висока девет спратова и чувала је збирку рукописа и ретких светих списа. У библиотеци је највише било дела из филозофије и религије, али и текстова о граматици, логици и књижевности, Веда и Веданта, Дармашастре, Пуране, као и дела из астрономије, астрологије и медицине. ${ }^{66}$ Постоји податак да је библиотека чувала око 700.000 наслова. ${ }^{67} \mathrm{O}$ богатству библиотеке и о развијеној пракси преписивања говори и податак да је Ји Цинг одавде понео око 400 рукописа на санскрту.

Бронзана повеља владара Девапале Деве из 14. века сведочи о дару бенгалског владара Девапале који, на молбу махараџе Палипутре Деве са острва Суматре, поклања пет села за одржавање манастира у Наланди, издржавање монаха и преписивање рукописа, што показује да се пракса даривања манастира није много разликовала од оне са наших простора. ${ }^{68}$

Мисија универзитета у Наланди заустављена је на самом крају 12. века, када га је Бакхтијар Кхилџи (?-1206) $)^{69}$ спалио. ${ }^{70}$ Библиотека, у којој је подметнут пожар, горела је месецима. ${ }^{71}$

Још једна виђенија библиотека овог типа постојала је при манастиру Викрамшила. ${ }^{72}$ Овај манастир и центар образовања основао је краљ Дхармапала у 8. веку наше ере.

Студенти из свих крајева Индије долазили су у Викрамшилу. Зна се да је ова институција имала 8000 студената, ${ }^{73}$ постоје извори који наводе да је број монаха научника на Викрамшили у 12. веку достигао 3000, као и да су овде многи познати научници писали текстове, преписивали рукописе на санскрту, често преводили и на тибетански језик. ${ }^{74}$ Институција ове величине захтевала је и одговарајућу библиотеку, која је била у физички одвојеном простору. Наставно веће било је задужено и за одржавање библиотеке. ${ }^{75}$ Овај универзитет такође је уништен услед муслиманских освајања.

Монашки универзитет који такође ваља споменути јесте Одантапури ${ }^{76}$ о коме тачне информације о оснивању нема, али се зна да је према том моделу изграђен први тибетански манастир 749. године. Краљеви из династије Пала проширили су универзитет даривајући му богату библиотеку будистичких и браманистичких списа. Одантапури је, нажалост, још један од збрисаних у походима поменутог муслиманског војсковође, а на месту универзитета изграђена је тврђава. ${ }^{77}$

Још један универзитет у северном Бенгалу био је значајан центар преписивачке активности у 12. веку. Џагагдал ${ }^{78}$ је у свом поседу неговао велелепну збирку рукописа, а што је можда још

${ }^{66}$ Bhatt, "Academic Libraries in India...", 56.

67 Петровић, Og Наланgе gо Хиланgара, 18

${ }_{68}$ Museums of India: National Portal \& Digital Repository, "Nalanda copper plate grant", preuzeto 2. 11. 2018, http://www.museumsofindia.gov.in/repository/record/nat_del-47-51-22228.

${ }^{69}$ Мухамед бин Бакхтијар Кхилџи (енг. Muhammad bin Bakhtiyar Khilji) био је војни генерал и први муслиман који је освојио Бенгал.

70 Bhatt, "Academic Libraries in India...", 56.

71 The Treasury of Lives, "Nalanda", preuzeto 30.1.2019, https://treasuryoflives.org/en/institution/Nalanda.

72 Викрамшила се налазила у северозападној Индији, на територији данашње државе Бихар.

73 Tahner and Gordon Davis Jr, Nav. delo, 32.

74 Најпознатији међу њима, Атиша Дипанкар Шри-Ђнана (982-1054), који се сматра једном од највећих личности класичног будизма и главном фигуром у његовомширењу током 11. века. Написао је преко 200 радова и, по позиву тибетанског краља Чан Чуба, отишао на Тибет како би реформисао будизам. Видети: Kumar Datta, Nav. delo, 28.

75 Tahner and Gordon Davis Jr, Nav. delo, 32.

76 У близини чувене Наланде и данашњег града Бихар Шариф, у држави Бихар.

77 Kumar Datta, Nav. delo, 29.

78 Овај монашки универзитет основао је краљ Рамапала (1084-1130) у Варендри. Универзитет је изнедрио многе значајне научнике и ауторе, међу којима је и Мокшакара Гупта, чувени индијски логичар. 
значајније, овде је професор (пандита) Данашила написао дело О значају иитиања књиіе (Риstakapathopaya), чији оригинал на санскрту није сачуван, али за дело се зна преко превода на тибетански који је начинио сам аутор. ${ }^{79}$

Библиотеку је поседовала и Митила, центар образовања намењен браманима, који је радио између 12. и 16. века. Овај универзитет интересантан је због начина на који је организован завршни испит. Студенти су били у обавези да оставе своје белешке на крају школовања, што је, наравно, пракса која је утицала на прогресивно увећавање библиотеке у Митили. Рукописи настали на овај начин били су веома корисни и на завршном полагању. Наиме, студент би иглом требало да прободе рукопис и задатак би му био да објасни страницу која је последња убодена. ${ }^{80}$

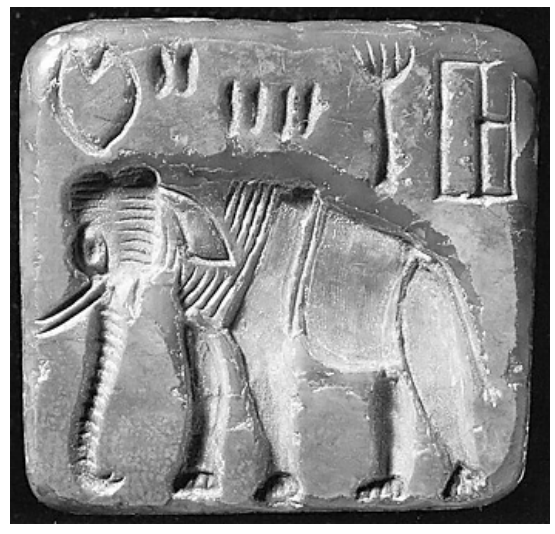

\section{Печат из Indus Script Dictionary}

Нзвор: Sci News, Indus Script Based on Sanskrit Language

http://www.sci-news.com/othersciences/linguistics/science-indus-script-sanskrit-language-01777.html

Једина библиотека овог типа о чијим се запосленима нешто зна радила је при академији званој Гатикасала у јужној Индији. У једном запису из 1092. године стоји да библиотека има шесторо запослених. Радни задаци ових библиотекара били су чување, обрада књига и вођење студената. Последња функција подразумевала је да је библиотекар високообразована особа коју студент може да консултује током учења. Ова библиотека давала је својим запосленима статус једнак наставном особљу.

Од библиотека при религијским центрима спомиње се неколико из старог века. Библиотека са читаоницом налазила се у хиндуистичком храму Никантешвара ${ }^{81}$ у Удајпуру у 11. веку. Ђаинистички храмови такође су чували писани материјал, а писање, преписивање и читање биле су свакодневне обавезе лаика. Библиотеке су се налазиле у подрумима како би списи били сачувани од сунчеве светлости и прашине. Кожне и дрвене кутије користиле су се за складиштење рукописа. Понекад су их покривали и памучном одећом. ${ }^{82} \mathrm{O}$ појединачним библиотекама из овог доба нема много информација јер су и оне биле мета напада муслиманских снага.

О приватним библиотекама у старој Индији готово да нема трагова. Велики научници овог доба сигурно су имали своје збирке, мада се то не може поуздано утврдити. У Ји Цинговим записима спомињу се приватне библиотеке монаха.

\footnotetext{
79 Kumar Datta, Nav. delo, 30.

${ }^{80} \mathrm{Ibid}, 32$.

81 Храм основан 1059. године постоји и данас. Посвећен је богу Шиви.

82 Tahner and Gordon Davis Jr, Nav. delo, 37.
} 


\section{Закључак}

Стара Индија добро чува, али и полако открива своје тајне. Навршава се готово цео век настојања да се проникне у значење записа из долине Инда. Њихово дешифровање допринело би упознавању човека ове цивилизације, а могло би и у знатној мери да промени досадашње поимање старог света и ове етапе у историји старе Индије.

У ведском, али и знатно каснијем периоду, староиндијски човек показао се као јако дисциплинован када је у питању усмено преношење знања. Веде које су се у јединственом облику одржавале широм Индије најбољи су доказ за то. Такав начин учења свакако није могао да изнедри библиотеке у смислу похрањених записа, али је зато од појединих брамана и других учених људи начинио живе библиотеке.

Осим у истрајној усменој традицији, изузетност старе Индије огледа се и у употреби неотпорних материјала за писање, који су доступни у природи и најчешће биљног порекла. Пергамент није долазио у обзир због благонаклоности индијског човека према свету који га окружује, што је пак повезан са природом религија које се на овом тлу развијају.

Са сигурношћу се може закључити да су библиотеке биле део индијског друштва у старом веку. Иако није познато колико их је укупно било при будистичким, а колико при другим центрима религије и образовања, сазнање да је највише трагова сачувано управо о онима при будистичким центрима, наводи на закључак да су будисти ти који су имали највећу потребу да оставе за собом записе, јер једино за њих спасење долази кроз знање. Недуговечни материјали на којима су текстови бележени подстицали су нове генерације свештеника, монаха и учењака на активнији однос и према учењу и према преписивању већ записаног.

Подаци о величини фондова, уређењу и организацији познати су тек за понеку библиотеку. Иако се о библиотекама у Индији до краја 12. века не зна превише, у прилог њиховој величини и значају говоре све војне акције које су имале циљ да се оне, заједно са центрима при којима су радиле, у потпуности униште и на тај начин избрише све на чему су индијски народи вековима радили. На темељима порушених библиотека и образовних центара градила се нова култура која је била под великим утицајем исламске, касније и европске цивилизације.

\section{Литература и извори:}

1. Bhatt, Raksesh Kumar. "Academic Libraries in India: A Historical Study". Rad predstavljen na International Conference on Academic Libraries: Vision and roles of the future academic libraries, New Delhi, India, 5-8. oktobar 2009. Preuzeto 20. 8. 2018. http://crl.du.ac.in/ical09/papers/ index_files/ical-10_180_494_2_RV.pdf.

2. Gul, Sumeer and Samina Khan. "Growth and Development of Oriental Libraries in India". Library Philosophy and Practice (April 2008). Preuzeto 15. 8. 2018.https://www.researchgate.net/ publication/234477140_Growth_and_Development_of_Oriental_Libraries_in_India.

3. Encyclopaedia Britannica. Preuzeto 17. 9. 2018. https://www.britannica.com/biography/Harsha.

4. Encyclopedia of Library and Information science. Vol. 39, Supplement 4. Allen Kent, ed. New York: M. Dekker, 1985.

5. Kumar Datta, Bimal. Libraries \& librarianship of Ancient and Medieval India. Delhi: ATMA RAM \& SONS, 1960.

6. Kumar, S. "Buddhist Monasticism ànd Education System: A Case Study Of India Korea Thailand And Tibet". Doktorska dis. Faculty of Humanities and Languages, Jamia Millia Islamia, New Delhi, 2016. Preuzeto 30. 1. 2019. http://hdl.handle.net/10603/211620.

7. Miler, Fridrih Maks. Vede: čemu nas Indija može naučiti. Beograd: Pešić i sinovi, 2005.

8. Museums of India: National Portal \& Digital Repository. "Nalanda copper plate grant". Preuzeto 30. 1. 2019. http://www.museumsofindia.gov.in/repository/record/nat_del-47-51-22228. 
9. Pajin, Dušan. „Staroindijsko narativno nasleđe - budistička i hinduistička tradicija”.U Istok: radovi sa naučnog skupa održanog u Novom Sadu 6. juna 2014. godine, uredio Nikola Grdinić, 116-158. Novi Sad: Zavod za kulturu Vojvodine, 2015.

10. Patel, Jashu and Krishan Kumar. Libraries and Librarianship in India. Westport: Greenwood Press, 2001.

11. Petrović, Aleksandar. Od Nalande do Hilandara. Novi Sad: Matica srpska; Beograd: Filološki fakultet Univerziteta, 2017.

12. Robinson, Andrew. "Ancient civilization: Cracking the Indus script". Nature 526 (22. 10. 2015). Preuzeto 15. 8. 2018. https://www.nature.com/news/

ancient-civilization-cracking-the-indus-script-1.18587.

13. Stipčević, Aleksandar. Povijest knjige. Zagreb: Nakladni zavod Matice Hrvatske, 1985.

14. Tahner, Mohamed and Donald Gordon Davis Jr. Librarianship and Library Science in India: An Outline of Historical Perspectives. New Delhi: Concept Publishing Company, 1994.

15. The British Library. Preuzeto 28. 9. 2018. https://www.bl.uk/collection-items/gandharan-scrolls. 16. The Treasury of Lives. "Nalanda". Preuzeto 30. 1. 2019. https://treasuryoflives.org/en/institution/ Nalanda.

17. Trehan, Girdhali Lai. Learning and Libraries in Ancient India: A Study. Chandigarh: Library Literary House, 1975.

\title{
Books and Libraries in Ancient India
}

\begin{abstract}
Summary
This paper is an attempt to present the role and significance of books and libraries on the Indian subcontinent to the local library public. The paper shows the attitude towards books and writing, as well as the course of founding libraries in the oldest developmental period, between 3000 BC and 1206 AD. The writing system, which is still waiting to be deciphered, existed in the Indus Valley Civilisation in the third millennium BC, as evidenced by numerous steatite seals and copper tablets with inscriptions on them. Little is known about the existence of manuscript collections on the territory of India BC. The reason for this is a great time distance, as well as a highly developed tradition of oral transmission of knowledge. Another reason is the practice of writing on materials with a low degree of durability such as palm leaf or birch bark. A turning point in relation to writing is brought by Buddhism, which in India dates back to the second half of the $6^{\text {th }}$ century $B C$, and significantly develops and receives new followers during the Mauryan dynasty, precisely during the reign of King Ashoka (273-236 BC). After converting himself to Buddhism, the king encouraged his subjects to convert, too. The oldest preserved monuments written in Ancient Indian scripts The Laws of King Ashoka carved in stone, originate from this period.

The first libraries in Ancient India about which we can speak with certainty, were the parts of mahaviharas, Buddhist monastic universities. The most famous and largest among them was the library in Nalanda. It was named Dharmaganjan which means Piety Mart, and according to some data, it had about 700,000 titles. Historical records reveal three types of libraries in ancient period. They are libraries attached to palaces/courts, educational centers, and religious centers.
\end{abstract}

Keywords: Ancient India, book, script, writing materials, mahavihara, palace/court libraries, libraries in educational centers, libraries in religious centers 


\section{(ब) $\triangle \Theta$}

Књига и библиотеке у Старој Индији bу Анђела Стошић is licensed under a Creative Commons AttributionNonCommercial-NoDerivatives 4.0 International License. 